\title{
Faktor-Faktor Yang Mempengaruhi Kinerja Karyawan Pada PT. Cahaya Timur Ogan Komering Ilir Sumatera Selatan
}

\author{
Reka Malinda \\ Manajemen, STIE Trisna Negara Belitang Sumsel \\ email: rekamalinda@stietrisnanegara.ac.id.
}

\begin{abstract}
ABSTRAK
Penelitian ini bertujuan untuk mengetahui apakah terdapat pengaruh motivasi kerja dan lingkungan kerja terhadap kinerja karyawan pada PT. Cahaya Timur Ogan Komering llir Sumatera Selatan. Pendekatan penelitian ini adalah kuantitatif dengan jenis explanatory research. Populasi dan sampel dalam penelitian ini adalah seluruh pegawai PT. Cahaya Timur Ogan Komering llir Sumatera Selatan, berjumlah 34 orang. Pengumpulan data menggunakan angket dan analisis data menggunakan analisis deskriptif, analisis regresi linier berganda, uji t, dan uji F. Penelitian ini menghasilkan kesimpulan bahwa motivasi kerja berpengaruh signifikan terhadap kinerja karyawan, lingkungan kerja berpengaruh signifikan terhadap kinerja karyawan dan secara simultan motivasi kerja dan lingkungan kerja berpengaruh signifikan terhadap kinerja karyawan.
\end{abstract}

Kata Kunci : Motivasi kerja, Lingkungan kerja dan kinerja karyawan

\section{A. Latar Belakang}

Dalam suatu sistem operasi perusahaan, potensi sumber daya manusia pada hakikatnya merupakan salah satu modal dan memegang suatu peran penting dalam mencapai tujuan perusahaan. Oleh karena itu perusahaan perlu mengolah sumber daya manusia sebaik mungkin. Sebab kunci kesuksesan suatu perusahaan bukan hanya pada keunggulan teknologi dan tersedianya modal tapi manusia atau tenaga kerja merupakan faktor terpenting bagi kemajuan perusahaan.

Hal ini menunjukkan bahwa sumber daya manusia merupakan kunci pokok yang harus diperhatikan dengan segala kebutuhannya. Memahami pentingnya keberadaan SDM di era global saat ini salah satu upaya yang harus dicapai oleh perusahaan adalah dengan meningkatkan kualitas SDM. Dengan meningkatkan kualitas sumber daya manusia diharapkan karyawan dapat meningkatkan kinerjanya.
Peningkatan kinerja karyawan di perusahaan dapat ditempuh dengan beberapa cara, misalnya melalui pemberian kompensasi yang layak, pemberian motivasi, menciptakan lingkungan kerja yang kondusif, serta pendidikan dan pelatihan. Oleh karena itu, karyawan diharapkan dapat memaksimalkan tanggung jawab mereka setelah dibekali dengan pendidikan dan pelatihan yang berkaitan dengan implementasi pekerjaan mereka.

Usaha untuk meningkatkan kinerja karyawan, diantaranya dengan memperhatikan motivasi dan lingkungan kerja para pegawai. Motivasi seseorang mempengaruhi cara mereka bersikap dan bekerja sehingga manajeman wajib mengatahui karakteristik karyawan. Maslow (Asim, 2013), menyatakan motivasi sebagai suatu reaksi yang diawali dengan adanya kebutuhan yang menumbuhkan keinginan atau upaya mencapai tujuan yang selanjutnya menimbulkan ketegangan yaitu keinginan yang belum terpenuhi, yang kemudian menyebabkan 
timbulnya tindakan yang mengarah kepada tujuan dan akhirnya akan memuaskan keinginan.

Motivasi kerja sangat mempengaruhi semangat kerja yang dimiliki oleh karyawan yang berpotensi untuk mencapai hasil yang optimal, sehingga diperlukan adanya pendorong agar karyawan mau mengerahkan seluruh potensinya. Seorang karyawan yang memiliki kinerja yang baik dapat menunjang tercapainya tujuan dan sasaran yang telah ditetapkan oleh perusahaan. Menurut Kiruja dan Elegwa (Kiruja, 2013) kinerja karyawan merupakan fungsi dari kemampuan dan motivasi, di mana kemampuan terdiri dari keterampilan, pelatihan dan sumber daya yang diperlukan untuk melakukan tugas dan motivasi digambarkan sebagai kekuatan batin yang mendorong individu untuk bertindak terhadap sesuatu.

Selain motivasi faktor yang mempengaruhi kinerja karyawan adalah lingkungan kerja. Lingkungan kerja merupakan segala sesuatu yang ada disekitar para pekerja yang dapat mempengaruhi dirinya dalam menjalankan tugas-tugas yang dibebankan. Menurut Sofyan (2013), "lingkungan kerja adalah segala sesuatu yang berada di sekitar karyawan yang mempengaruhi dirinya dalam menjalankan dan menyelesaikan tugas-tugas yang diberikan kepadanya dalam suatu wilayah". Faktor lingkungan kerja yang diharapkan oleh karyawan juga mempengaruhi kinerja karyawan tersebut dalam menyelesaikan pekerjaannya. Lingkungan kerja yang kondusif sangat dibutuhkan organisasi demi tercapainya tujuan, karena lignkungan adalah tempat dimana karyawan bekerja. Lingkungan kerja yang baik dapat membuat seseorang nyaman sehingga bisa berdampak pada kinerja seorang karyawan. Lingkungan kerja yang menyenangkan bagi pegawai melalui peningkatan hubungan yang harmonis dengan atasan, rekan kerja, maupun bawahan, serta dukungan oleh sarana dan prasarana yang memadai yang ada di tempat kerja akan membawa dampak yang positif bagi pegawai sehingga kinerja pegawai dapat meningkat.

Dari observasi yang dilakukan pada PT. Cahaya Timur Ogan Komering Ilir Sumatera Selatan dapat dilihat dari masih adanya pegawai yang melaksanakan tugasnya yang kurang profesional, seperti kurang memahami tugas dan fungsinya, masih adanya pegawai yang sering menunda-nunda pekerjaan, terlambat masuk kerja, kurang memanfaatkan waktu kerja dengan baik. Keadaan yang demikian akan mempengaruhi kinerja mereka tidak bisa secara optimal karena pegawai kurang memiliki motivasi untuk melakukan ketentuan yang telah ditetapkan oleh organisasi.

Berdasarkan latar belakang masalah diatas maka penulis tertarik untuk megambil judul penelitian "Faktor-faktor yang mempengaruhi kinerja karyawan pada PT. Cahaya Timur Ogan Komering Ilir Sumatera Selatan"

\section{B. Rumusan Masalah}

Berdasarkan latar belakang di atas, maka penulis merumuskan masalah sebagai berikut :

1) Apakah ada pengaruh motivasi kerja terhadap kinerja karyawan pada PT. Cahaya Timur Ogan Komering Ilir Sumatera Selatan?

2) Apakah ada pengaruh lingkungan kerja terhadap kinerja karyawan pada PT. Cahaya Timur Ogan Komering Ilir Sumatera Selatan? 
3) Apakah ada pengaruh motivasi kerja dan lingkungan kerja terhadap kinerja karyawan pada PT. Cahaya Timur Ogan Komering Ilir Sumatera Selatan?

\section{KAJIAN TEORI \\ 1. Motivasi Kerja}

Motivasi beraasal dari kata Latin movere yang berarti dorongan atau menggerakan. Motivasi (Motivation) dalam manajeman hanya ditunjukkan pada sumber daya manusia umumnya dan bawahan khususnya.

Menurut Mulyadi (2015) Motivasi adalah suatu dorongan baik dari orang lain maupun dari diri sendiri untuk mengerjakan suatu pekerjaan denagn sadar dan semangat untuk mencapai target tertentu. Sedangkan Anwar Prabu Mangkunegara (2011), "motivasi adalah kondisi yang menggerakkan pegawai agar mampu mencapai tujuan dari motifnya." Dalam hal ini, motif berarti kehendak atau tujuan yang ingin dicapai. Motivasi melibatkan tujuan yang memberikan dorongan dan arahan untuk tindakan. Sebagaimana menurut Schunk, Pintrich, \& Meece (2010), "motivation involves goals that provide impetus for and direction to action."

Motivasi diperlukan sebagai daya penggerak bagi seseorang dalam menjalankan aktivitasnya. Tanpa motivasi yang tinggi, seseorang akan merasa berat dalam bekerja. Menurut Suwardi \& Joko Utomo (2011), "motivasi kerja yang tepat akan mampu memajukan dan mengembangkan organisasi karena pegawai akan melaksanakan tugas sesuai dengan bidangnya atas dasar kesadaran."

Dari pendapat dari para ahli diatas dapat disimpulkan bahwa Motivasi adalah berbagai usaha yang dilakukan oleh manusia tentunya untuk memenuhi keinginan dan kebutuhannya. Namun, agar keinginan dan kebutuhannya dapat terpenuhi tidaklah mudah didapat apabila tanpa usah yang maksimal. Dalam pemenuhan kebutuhannya, seseorang akan berperilaku sesuai dengan dorongan yang dimiliki dan apa yang mendasari perilakunnya

\section{Lingkunan Kerja}

Lingkungan kerja dalam suatu perusahaan perlu diperhatikan, hal ini disebabkan karena lingkungan kerja mempunyai pengaruh langsung terhadap para pegawai. Lingkungan kerja yang kondusif dapat meningkatkan kinerja pegawai dan sebaliknya, lingkungan kerja yang tidak memadai akan dapat menurunkan kinerja pegawai.

Lingkungan kerja berpengaruh terhadap kinerja karyawan. Sebagaimana dikemukakan oleh Andamdewi (2013) bahwa, "lingkungan kerja yang kondusif memungkinkan pegawai bekerja lebih bersemangat, sehingga hasil kerjanya lebih memuaskan." Selanjutnya, Sedarmayanti (2011) lingkungan kerja adalah keseluruhan alat perkakas dan bahan yang dihadapi, lingkungan sekitarnya dimana seseorang bekerja, metode kerjanya, serta pengaturan kerjanya baik sebagai perorangan maupun sebagai kelompok.

Berdasarkan definisi tersebut, dapat diketahui bahwa lingkungan kerja adalah kondisi atau keadaan yang mempengaruhi terhadap kinerja seseorang.

\section{Kinerja Karyawan}

Kinerja merupakan perilaku nyata yang ditampilkan setiap orang sebagai kinerja pegawai yang dihasilkan oleh pegawai sesuai dengan perannya dalam organisasi atau instansi. Kinerja pegawai merupakan suatu hal yang 
sangat penting dalam upaya instansi untuk mencapai tujuan.

Menurut Mangkunegara (2011) pengertian kinerja (prestasi kerja) adalah hasil kerja secara kualitas dan kuantitas yang dicapai oleh seorang pegawai dalam melaksanakan tugasnya sesuai dengan tanggung jawab yang diberikan kepadanya. Darmawan (2013) menyebutkan bahwa kinerja sebagai hasil kerja yang dicapai seseorang secara kualitas dan kuantitas harus dipantau secara terus menerus perkembangannya, pemantauan akan memberikan informasi apakah kinerja karyawan telah sesuai dengan harapan organisasi.

Wibowo (2013), menjelaskan kinerja merupakan kegiatan pengelolahan sumber daya organisasi untuk mencapai tujuan organisasi. Kinerja pegawai merupakan suatu hal yang sangat penting dalam usaha organisasi mencapai tujuannya, sehingga berbagai kegiatan harus dilakukan organisasi tersebut untuk meningkatkannya. Selanjutnya, Dharma (2012) juga mengemukakan bahwa, "pada hakikatnya, kinerja merupakan prestasi yang dicapai oleh seseorang dalam melaksanakan tugasnya atau pekerjaannya sesuai dengan standar dan kriteria yang ditetapkan untuk pekerjaan itu."
Menurut pengertian di atas, bahwa kinerja pegawai adalah prestasi kerja atau hasil kerja (output) baik kualitas maupun kuantitas yang dicapai SDM persatuan periode waktu dalam melaksanakan tugas kerjanya sesuai dengan tanggung jawab yang diberikan kepadanya.

\section{Metode Penelitian}

Berdasarkan tujuan penelitian yang telah ditetapkan, maka jenis penelitian ini dapat digolongkan sebagai penelitian penjelasan atau eksplanatori. Populasi pada penelitian ini adalah semua karyawan pada PT. Cahaya Timur Ogan Komering Ilir Sumatera Selatan dengan jumlah 34 karyawan dan teknik pengambilan sampel yang dipakai dalam penelitian ini adalah sampel jenuh yaitu menentukan sampel dengan semua anggota populasi digunakan sebagai sampel. Pemilihan teknik tersebut dikarenakan jumlah populasi yang kecil dan kurang dari 100 orang. Teknik analisis data yang digunakan adalah analisis statistik deskriptif dan analisis statistik inferential dengan melakukan uji kualitas data yaitu uji validitas dan uji reliabilitas, selanjutnya dilakukan uji asumsi klasik yaitu uji normalitas, uji multikolonearitas dan uji heteroskedastisitas dan terakhir melakukan uji hipotesis yaitu uji $F$ dan uji t. 
E. Hasil Penelitian

Hasil Uji Coba Instrumen

a. Uji Validitas

Tabel 1. Hasil Uji Validitas

\begin{tabular}{|c|c|c|c|c|c|}
\hline \multirow{2}{*}{ Variabel } & \multirow{2}{*}{ Butir } & \multicolumn{4}{|c|}{ Skor Total } \\
\hline & & $\mathbf{r}_{\text {hitung }}$ & $r_{\text {tabel }}$ & $\mathbf{N}$ & Keterangan \\
\hline \multirow{10}{*}{$\begin{array}{c}\text { Motivasi Kerja } \\
\left(\mathrm{X}_{1}\right)\end{array}$} & 1 & 0.583 & \multirow{10}{*}{0,339} & \multirow{10}{*}{34} & Valid \\
\hline & 2 & 0.411 & & & Valid \\
\hline & 3 & 0.754 & & & Valid \\
\hline & 4 & 0.467 & & & Valid \\
\hline & 5 & 0.632 & & & Valid \\
\hline & 6 & 0.809 & & & Valid \\
\hline & 7 & 0.743 & & & Valid \\
\hline & 8 & 0.761 & & & Valid \\
\hline & 9 & 0.742 & & & Valid \\
\hline & 10 & 0.704 & & & Valid \\
\hline \multirow{10}{*}{$\begin{array}{l}\text { Lingkungan Kerja } \\
\qquad\left(\mathrm{X}_{2}\right)\end{array}$} & 1 & 0.651 & \multirow{10}{*}{0,339} & \multirow{10}{*}{34} & Valid \\
\hline & 2 & 0.422 & & & Valid \\
\hline & 3 & 0.898 & & & Valid \\
\hline & 4 & 0.827 & & & Valid \\
\hline & 5 & 0.471 & & & Valid \\
\hline & 6 & 0.868 & & & Valid \\
\hline & 7 & 0.519 & & & Valid \\
\hline & 8 & 0.502 & & & Valid \\
\hline & 9 & 0.585 & & & Valid \\
\hline & 10 & 0.695 & & & Valid \\
\hline \multirow{10}{*}{$\begin{array}{l}\text { Kinerja Karyawan } \\
\text { (Y) }\end{array}$} & 1 & 0.466 & \multirow{10}{*}{0,339} & \multirow{10}{*}{34} & Valid \\
\hline & 2 & 0.676 & & & Valid \\
\hline & 3 & 0.691 & & & Valid \\
\hline & 4 & 0.548 & & & Valid \\
\hline & 5 & 0.594 & & & Valid \\
\hline & 6 & 0.637 & & & Valid \\
\hline & 7 & 0.520 & & & Valid \\
\hline & 8 & 0.662 & & & Valid \\
\hline & 9 & 0.586 & & & Valid \\
\hline & 10 & 0.520 & & & Valid \\
\hline
\end{tabular}

Sumber : Hasil Pengolahan Data Primer

Dari hasil pengolahan data uji coba instrument ketiga variabel keseluruhan vailid dengan $r_{\text {hitung }}$ lebih besar dari pada $r_{\text {tabel }}$ sehingga keseluruhan item pertanyaan yang ada pada instrument terebut dapat dijadikan sebagai alat ukur yang valid dalam analisis selanjutnya.

b. Uji Reliebilitas

Tabel 2. Rekapitulasi Hasil Uji Reliabilitas

\begin{tabular}{cc}
\hline Variabel & $\begin{array}{c}\text { Nilai } \\
\text { Cronbach's }\end{array}$ \\
\hline Motivasi Kerja $\left(X_{1}\right)$ & 0,844 \\
\hline
\end{tabular}

Lingkungan Kerja $\left(\mathrm{X}_{2}\right) \quad 0,849$

Kinerja Karyawan $(Y) \quad 0,766$

Sumber : Hasil Pengolahan Data Primer

Hasil uji reliabilitas berdasarkan tabel di atas ketiga variabel di dapat nilai Cronbach's Alpha $>0,60$ karena nilai diatas 0,60 maka dapat disimpulkan bahwa alat ukur dalam penelitian ini reliabel (dapat dipercaya), dan dapat dijadikan alat ukur dianalisis selanjutnya. 


\section{Hasil Uji Asumsi Klasik}

\section{a. Uji Normalitas}

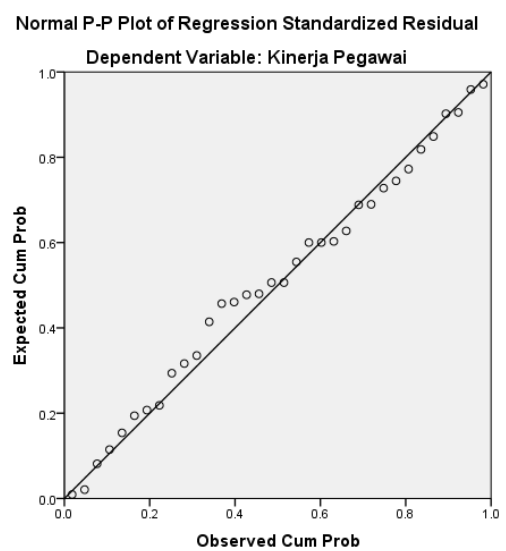

Berdasarkan hasil perhitungan pada gambar diatas tersebut menjelaskan pada grafik normal probability plot garis (titik-titik) mengikuti garis diagonal yang artinya suatu data menunjukkan berdistribusi normal sehingga model persamaan regresi memenuhi asumsi normalitas.

\section{b. Uji Multikolonearitas}

Tabel 3. Hasil Uji Multikolinearitas

\begin{tabular}{lcc}
\hline \multicolumn{1}{c}{ Variabel bebas } & Tolerance & VIF \\
\hline Motivasi Kerja $\left(\mathrm{X}_{1}\right)$ & 0.402 & 2.487 \\
\hline Lingkungan Kerja $\left(\mathrm{X}_{2}\right)$ & 0.402 & 2.487 \\
\hline
\end{tabular}

Sumber : Hasil Pengolahan Data Primer

Hasil pengujian menunjukkan bahwa semua variabel yang digunakan sebagai prediktor model regresi menunjukkannilai Tolerance lebih dari 0,10 dan nilai VIF kurang dari 10. Ini berarti bahwa tidak terjadi multikolinieritas antar variabel bebas.

\section{c. Uji Heteroskedastisitas}

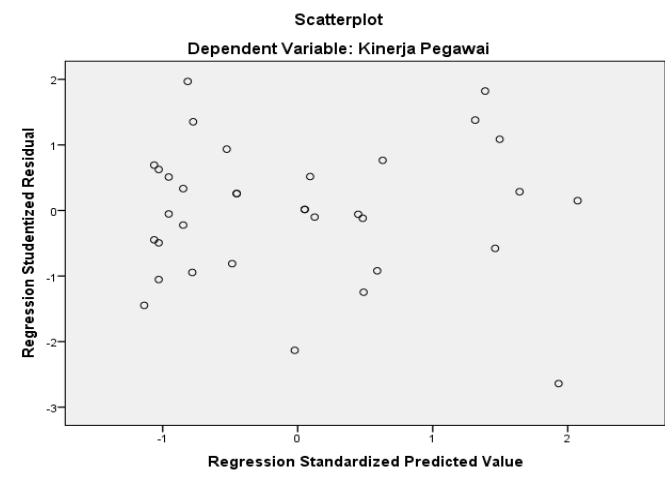

Hasil

pengujian

heteroskedastisitas menunjukkan hasil output didapatkan titik-titik menyebar dan tidak mempunyai pola yang teratur, jadi kesimpulannya variabel bebas di atas tidak terjadi heteroskedastisitas.

\section{F. Pembahasan}

a. Uji Regresi Linier Berganda

Analisis koefisien regresi pada dasarnya merupakan pengujian terhadap derajat signifikansi hubungan dan besarnya pengaruh variabel bebas terhadap variabel terikat. Analisis ini dilakukan dengan dua cara, yaitu: (1) dengan uji $F$ yang digunakan untuk mengetahui besarnya koefisien regresi atau menguji tingkat signifikansi kedua variabel bebas terhadap variabel terikat; dan (2) dengan melihat koefisien regresi parsial yang dapat digunakan untuk mengetahui besarnya pengaruh masing-masing variabel bebas terhadap variabel terikat.

Adapun dari hasil perhitungan dengan menggunakan bantuan program komputer SPSS 22.0 for windows, maka dapat diperoleh persamaan regresi sebagai berikut:

Tabel 4. Hasil Uji Regresi Linear Berganda

\begin{tabular}{|c|c|c|c|c|}
\hline \multirow{2}{*}{\multicolumn{2}{|c|}{ Model }} & \multicolumn{2}{|c|}{ Unstandardized Coefficients } & Standardized Coefficients \\
\hline & & B & Std. Error & Beta \\
\hline & (Constant) & .784 & .399 & \\
\hline \multirow[t]{2}{*}{1} & Motivasi Kerja & .518 & .151 & .515 \\
\hline & Lingkungan Kerja & .307 & .120 & .384 \\
\hline
\end{tabular}

Sumber : Hasil Pengolahan Data Primer 
Model persamaan regresi yang dapat dituliskan dari hasil tersebut dalam bentuk persamaan regresi berganda adalah sebagai berikut :

$Y=0,784+0,518 X_{1}+0,307 X_{2}+e$

1. Nilai konstanta 0,784 menunjukkan bahwa apabila tidak ada variabel independen (motivasi kerja dan lingkungan kerja) $=0$, maka kinerja karyawan adalah 0,784 satuan.

2. Koefisien regresi $b_{1} \quad(0,518)$ mempunyai nilai positif, ini menunjukkan bahwa jika variabel motivasi kerja ditingkatkan sebesar 1 satuan dan lingkungan kerja dianggap konstan maka kinerja karyawan akan meningkat sebesar 0,518 satuan..

3. Koefisien regresi $b_{2} \quad(0,307)$ mempunyai nilai positif, ini menunjukkan bahwa jika variabel lingkungan kerja ditingkatkan sebesar 1 satuan dan motivasi kerja dianggap konstan maka kinerja karyawan akan meningkat sebesar 0,307 satuan.

b. Uji Koefisien Korelasi

Tabel 5. Hasil Uji Koefisien Korelasi

\begin{tabular}{ccr}
\hline $\mathrm{R}$ & $\mathrm{R}$ Square & $\begin{array}{c}\text { Std. Error of the } \\
\text { Estimate }\end{array}$ \\
\hline $.848^{\mathrm{a}}$ & .718 & .18456 \\
\hline Sumber : Hasil Pengolahan Data Primer
\end{tabular}

Berdasarkan hasil perhitungan menjelaskan nilai korelasi $(R)$ sebesar $0,848^{a}$ hal ini menunjukkan hubungan yang kuat antara variabel motivasi kerja $\left(X_{1}\right)$ dan lingkungan kerja $\left(X_{2}\right)$ terhadap kinerja karyawan (Y). Hubungannya positif (searah) artinya antara variabel motivasi kerja $\left(\mathrm{X}_{1}\right)$ dan lingkungan kerja $\left(\mathrm{X}_{2}\right)$ terhadap kinerja karyawan $(\mathrm{Y})$, bila nilai motivasi kerja $\left(X_{1}\right)$ dan lingkungan kerja $\left(X_{2}\right)$ meningkat maka tingkat kinerja karyawan (Y) juga akan meningkat. Dan sebaliknya jika nilai motivasi kerja $\left(X_{1}\right)$ dan lingkungan kerja $\left(X_{2}\right)$ menurun maka tingkat kinerja karyawan $(Y)$ juga akan menurun.

c. Uji Koefisien Determinasi $\left(\mathbf{R}^{2}\right)$ Tabel 6. Hasil Uji Koefisien Determinasi R Square Adjusted R Std. Error of the

\begin{tabular}{ccc} 
& Square & Estimate \\
\hline .718 & .700 & .18456 \\
\hline Sumber $:$ Hasil Pengolahan Data Primer
\end{tabular}

Sumber : Hasil Pengolahan Data Primer

Berdasarkan hasil pengujian koefisien determinasi menunjukkan bahwa nilai $R^{2}$ sebesar 0,700 . Hal ini berarti sebesar $70 \%$ tingkat kinerja karyawan dapat dijelaskan oleh variabel motivasi kerja dan lingkungan kerja, sedangkan sisanya dipengaruhi oleh variabel lain diluar model.

\section{d. Uji F ( Uji Secara Simultan)}

Tabel 7. Hasil Uji F

\begin{tabular}{llrrr}
\hline & Model & $\mathrm{df}$ & $\mathrm{F}$ & Sig. \\
\hline & Regression & 2 & 39.539 & $.000^{\mathrm{b}}$ \\
1 & Residual & 31 & & \\
& Total & 33 & & \\
\hline Sumber : Hasil Pengolahan Data Primer
\end{tabular}

\section{Pengaruh motivasi kerja dan Lingkungan kerja terhadap kinerja karyawan}

Pengujian secara simultan menunjukkan bahwa nilai $F$ hitung untuk model regresi adalah 39,539 dengan tingkat signifikansi $0,000<$ 0,05 maka tingkat signifikansi model regresi lebih kecil dari taraf nyata. Hasil ini menunjukkan bahwa variabel bebas yaitu motivasi kerja dan lingkungan kerja secara simultan mempunyai pengaruh yang signifikan terhadap variabel terikat yaitu kinerja karyawan. Dari hasil ini dapat diketahui bahwa untuk meningkatkan kinerja karyawan perusahaan perlu memperhatikan faktor motivasi kerja dan lingkungan kerja.

$$
\text { Motivasi kerja sangat }
$$
mempengaruhi semangat kerja yang dimiliki oleh karyawan yang berpotensi untuk mencapai hasil yang optimal, sehingga diperlukan adanya pendorong agar karyawan mau 
mengerahkan seluruh potensinya. Faktor lingkungan kerja yang diharapkan oleh karyawan juga mempengaruhi kinerja karyawan tersebut dalam menyelesaikan pekerjaannya. Lingkungan kerja yang kondusif sangat dibutuhkan organisasi demi tercapainya tujuan, karena lignkungan adalah tempat dimana karyawan bekerja. Lingkungan kerja yang baik dapat membuat seseorang nyaman sehingga bisa berdampak pada kinerja seorang karyawan.

Hasil penelitian ini di dukung penelitian yang dilakukan oleh Eliyanto (2018) bahwa motivasi kerja dan lingkungan kerja berpengaruh signifikan terhadap kinerja karyawan

e. Uji t ( Uji Secara Parsial) Tabel 8. Hasil Uji t

\begin{tabular}{llr}
\hline Model & $\mathrm{t}$ & \multicolumn{1}{c}{ Sig. } \\
\hline (Constant) & 1.966 & .058 \\
Motivasi Kerja & 3.425 & .002 \\
Lingkungan Kerja & 2.555 & .016 \\
\hline Sumber : Hasil Pengolahan Data Primer &
\end{tabular}

\section{Pengaruh motivasi kerja terhadap kinerja karyawan}

Hasil uji untuk variabel $\mathrm{X}_{1}$ (motivasi kerja) diperoleh nilai thitung $=$ 3,425 dengan taraf signifikansi 0,002. Dengan menggunakan batas 0,05 didapat tabel sebesar 2,037 $(\mathrm{df}=\mathrm{n}-2=$ $34-2=32$ ). Ini berarti thitung $>$ tabel $=$ $3,425>2,037$ dengan demikian berarti bahwa motivasi kerja secara parsial berpengaruh signifikan terhadap kinerja karyawan. Artinya semakin tinggi motivasi dan semakin sering motivasi dilakukan maka kinerja karyawan akan mengalami peningkatan secara signifikan dan sebaliknya, kurangnya motivasi akan menurunkan kinerja karyawan. Hasil penelitian ini mendukung pendapat Uno (2011), yang menyatakan bahwa motivasi adalah faktor yang mendorong seseorang untuk mengadakan perubahan aktivitas tertentu secara lebih baik dari keadaan sebelumnya.

Motivasi yang ada dalam diri karyawan sangatlah penting, sehingga karyawan akan senantiasa melakukan suatu pekerjaan dengan penuh semangat dan rasa senang. Dengan motivasi tinggi pula dapat menciptakan kompetisi antar karyawan secara sehat agar menjadi karyawan yang berprestasi. Hal ini tentunya dapat meningkatkan kinerja karyawan ke tingkat yang lebih tinggi karena seluruh sumber daya manusia yang ada bekerja dengan motivasi tinggi.

Hasil penelitian ini selaras dengan penelitian dari Wicaksono (2014), Wungkana, Winda dkk (2015), Hanafi, Bayu Dwilaksono \& Corry Yohana. (2017) dan Eliyanto (2018) bahwa motivasi berpengaruh positif dan signifikan terhadap kinerja karyawan.

\section{Pengaruh Lingkungan kerja terhadap kinerja karyawan}

Hasil uji untuk variabel $\mathrm{X}_{2}$ (lingkungan kerja) diperoleh nilai thitung $=2,555$ dengan taraf signifikansi 0,016 . Dengan menggunakan batas 0,05 didapat tabel sebesar 2,037 (df = $\mathrm{n}-2=34-2=32$ ). Ini berarti thitung $>$ ttabel $=2,555>2,037$ dengan demikian berarti bahwa lingkungan kerja secara parsial berpengaruh signifikan terhadap kinerja karyawan. ini menunjukkan bahwa untuk mempertahankan dan meningkatkan kinerja karyawan, maka faktor lingkungan perlu diperhatikan keberadaannya. Lingkungan kerja perlu dijaga bersama guna memberikan rasa nyaman bagi guru dalam bekerja.

Menurut pendapat Sari Andamdewi (2013: 211), bahwa lingkungan kerja yang kondusif memungkinkan pegawai bekerja lebih semangat, sehingga hasil 
kerjanya lebih memuaskan." Penciptaan lingkungan kerja yang baik perlu dilakukan guna menjaga kesehatan dan kenyamanan serta kelancaran dalam bekerja. Terutama aspek penerangan, sirkulasi udara, dan kebersihan lingkungan perlu diperhatikan untuk meningkatkan kinerja karyawan.

Lingkungan kerja yang konduktif yang diciptakan oleh pegawai dan perusahaan akan mendorong efektivitas dari perusahaan tersebut didalam menjalankan roda organisasinya. Serta akan menimbulkan semangat dan gairah kerja yang tinggi karena adanya lingkungan kerja yang baik dan menyenangkan (Budianto dan Amelia Katini, 2015).

Hasil penelitian ini sesuai dengan penelitian Budianto \& Amelia Katini (2015), Eliyanto (2018), Wungkana, Winda dkk (2015), Wijaya Hendry \& Emi Susanty (2017) bahwa lingkungan kerja berpengaruh signifikan terhadap kinerja karyawan namun penelitian ini tidak sejalan dengan penelitian yang dilakukan oleh Hanafi, Bayu Dwilaksono \& Corry Yohana. (2017) menyatakan bahwa lingkungan kerja tidak berpengaruh signifikan terhadap kinerja karyawan

\section{G. Kesimpulan dan Saran \\ a. Kesimpulan}

Berdasarkan dari permasalahan yang dibahas pada rumusan masalah diatas, maka hasil penelitian ini dapat disimpulkan sebagai berikut :

1. Motivasi kerja berpengaruh signifikan terhadap kinerja karyawan.

2. Lingkungan kerja berpengaruh signifikan terhadap kinerja karyawan.

3. Motivasi kerja dan lingkungan kerja berpengaruh signifikan terhadap kinerja karyawan.

\section{b. Saran}

Berdasarkan simpulan diatas, maka diberikan beberapa saran yang kiranya dapat bermanfaat bagi pihakpihak yang berkepentingan. Adapun saran-saran yang penulis dapat berikan adalah :

1. Dari hasil penelitian diketahui bahwa faktor motivasi kerja dan lingkungan kerja berpengaruh terhadap kinerja karyawan, maka hal ini perlu diperhatikan oleh perusahaan mengenai motivasi dan lingkungan kerja.

2. Diharapkan untuk peneliti selanjutnya dapat mengkaji lebih dalam tentang motivasi kerja dan lingkungan kerja yang berpengaruh terhadap kinerja karyawan agar diperoleh gambaran yang lebih lengkap lagi, sehingga diharapkan hasil penelitian yang akan datang lebih baik lagi.

\section{DAFTAR PUSTAKA}

Andamdewi, Sari. (2013). Hubungan Lingkungan Kerja dengan Motivasi Kerja Pegawai Bagian Sekretariat Dinas Tenaga Kerja dan Transmigrasi Provinsi Sumatera Barat. Jurnal Administrasi Pendidikan, 1, 1, 211.

Asim, M. (2013). Impact of motivation on employee performance with effect of training: specific to education sector of Pakistan. International Journal of Scientific and Research Publications, 3, 1-9.

Budianto, A.Aji Tri dan Amelia Katini. (2015). Pengaruh Lingkungan Kerja Terhadap Kinerja Pegawai Pada PT Perusahaan Gas Negara (Persero) Tbk SBU 
Distribusi Wilayah I Jakarta. Kreatif. Jurnal Ilmiah Prodi Manajemen Universitas Pamulang. Vol. 3, No.1, Oktober 2015. hal. 100-124.

Darmawan, Didit. (2013). PrinsipPrinsip Perilaku Organisasi, Cetakan Pertama. Surabaya: Pena Semesta.

Dharma, Surya. (2012). Manajemen Kinerja: Falsafah, teori, dan Penerapannya. Yogyakarta: Pustaka Pelajar.

Eliyanto. (2018). Pengaruh Motivasi Kerja dan Lingkungan Kerja terhadap Kinerja Guru SMA Muhammadiyah di Kabupaten Kebumen. Jurnal Pendidikan Madrasah, Volume 3, Nomor 1, Mei 2018

Hanafi, Bayu Dwilaksono \& Corry Yohana. (2017). Pengaruh Motivasi, Dan Lingkungan Kerja, Terhadap Kinerja Karyawan, Dengan Kepuasan Kerja Sebagai Variabel Mediasi Pada PT BNI Life insurance. Jurnal Pendidikan Ekonomi dan Bisnis (JPEB)Vol. 5No.1 Maret 2017.

Kiruja, E. K. (2013). Effect of Motivation on Employee Performance In Public Middle Level Technical Training Institutions In Kenya. International Journal of Advances in Management and Economics, 2, 73-82.

Mangkunegara, A. A. Anwar Prabu. (2011). Manajemen Sumber Daya Manusia, Cetakan Kesepuluh. Bandung: PT. Remaja Rosdakarya Offset.

Mulyadi. 2015. Manajemen Sumber Daya Manusia. Penerbit in Media Bogor.
Sedarmayanti, 2011. Tata Kerja Dan Produktivitas Kerja (Suatu Tinjauan Dari Aspek Ergonomi Atau Kaitan Antara Manusia Dengan Lingkungan Kerjanya). Bandung: CV. Mandar Maju.

Suwardi \& Utomo, Joko. (2011). Pengaruh Motivasi Kerja, Kepuasan Kerja, dan Komitmen Organisasional terhadap Kinerja Pegawai. Jurnal Analisis Manajemen, 5, 1, 78.

Uno, Hamzah B. (2011). Teori Motivasi dan Pengukurannya. Jakarta: Bumi Aksara.

Wibowo, 2013, Manajemen Kinerja, Penerbit PT. Raja Grafindo Persada, Jakarta

Wicaksono, R. P. (2014). Pengaruh Motivasi Kerja dan Disiplin Kerja Terhadap Kinerja Karyawan (Studi Kasus pada PT. Stars International Kota Surabaya). Jurnal Administrasi Bisnis, 11(1).

Wijaya, Hendry \& Emi Susanty. (2017). Pengaruh Lingkungan Kerja Terhadap Kinerja Pegawai Pada Instansi Pemerintah Daerah Kabupaten Musi Banyuasin (Studi Kasus Dinas Pertambangan dan Energi Kabupaten Musi Banyuasin). Jurnal Ecoment Global. Volume 2 Nomor 1 Edisi Februari 2017.

Wungkana, Winda; Peggy A Mekel; Mac Donald Walangitan. (2015). Pengaruh Lingkungan Kerja, Motivasi Dan Pengembangan Karir Terhadap Kinerja Karyawan PT Telkom Manado. Jurnal Berkala IImiah Efisiensi Volume 15 No. 05 Tahun 2015. 